\title{
Article \\ Chemical Modification of Agro-Industrial Waste-Based Bioadsorbents for Enhanced Removal of Zn(II) Ions from Aqueous Solutions
}

\author{
David Castro ${ }^{1}$, Nelly Ma. Rosas-Laverde ${ }^{1, *}$, María Belén Aldás ${ }^{2}$, Cristina E. Almeida-Naranjo ${ }^{3}$, \\ Víctor H. Guerrero ${ }^{1}$ and Alina Iuliana Pruna $4,5, *$ (D) \\ 1 Department of Materials, Escuela Politécnica Nacional, Quito 170524, Ecuador; \\ da.castro92@outlook.com (D.C.); victor.guerrero@epn.edu.ec (V.H.G.) \\ 2 Department of Civil and Environmental Engineering, Escuela Politécnica Nacional, Quito 170524, Ecuador; \\ maria.aldas@epn.edu.ec \\ 3 Department of Mechanical Engineering, Escuela Politécnica Nacional, Quito 170524, Ecuador; \\ cristina.almeidan@epn.edu.ec \\ 4 Institute of Materials Technology, Universitat Politècnica de València, 46022 Valencia, Spain \\ 5 Center for Surface Science and Nanotechnology, University Politehnica of Bucharest, \\ 313 Splaiul Independentei, 060042 Bucharest, Romania \\ * Correspondence: nelly.rosas@epn.edu.ec (N.M.R.-L.); apruna@itm.upv.es (A.I.P.)
}

\section{check for} updates

Citation: Castro, D.; Rosas-Laverde, N.M..; Aldás, M.B.; Almeida-Naranjo, C.E.; Guerrero, V.H.; Pruna, A.I.

Chemical Modification of

Agro-Industrial Waste-Based

Bioadsorbents for Enhanced Removal of $\mathrm{Zn}$ (II) Ions from Aqueous

Solutions. Materials 2021, 14, 2134.

https://doi.org/10.3390/ma14092134

Academic Editors: Andreas Taubert and Andrea Petrella

Received: 8 March 2021

Accepted: 19 April 2021

Published: 22 April 2021

Publisher's Note: MDPI stays neutral with regard to jurisdictional claims in published maps and institutional affiliations.

Copyright: (c) 2021 by the authors. Licensee MDPI, Basel, Switzerland. This article is an open access article distributed under the terms and conditions of the Creative Commons Attribution (CC BY) license (https:// creativecommons.org/licenses/by/ $4.0 /)$.
Abstract: Contamination of water by heavy metals is a major environmental concern due to the potential ecological impact on human health and aquatic ecosystems. In this work, we studied the chemical modification of various fruit peels such as banana (BP), granadilla (GP), and orange ones $(\mathrm{OP})$ in order to obtain novel bio-adsorbents to improve the removal of $\mathrm{Zn}$ (II) ions from $50 \mathrm{mg} \cdot \mathrm{L}^{-1}$ synthetic aqueous solutions. For this purpose, sodium hydroxide and calcium acetate were employed to modify the fruit peels. The moisture, extractives, lignin, hemicellulose, and cellulose contents of the raw materials were determined according to ASTM standards. The obtained bio-adsorbents were characterized by scanning electron microscopy (SEM), Fourier Transform Infrared Spectroscopy (FTIR) and thermogravimetric analysis (TGA). The results showed the OP bio-adsorbents performed better, especially when the concentration of the modifier solutions increased, e.g., the OP particles modified using $0.8 \mathrm{M} \mathrm{NaOH}$ and $\mathrm{Ca}\left(\mathrm{CH}_{3} \mathrm{COO}\right)_{2}$ solutions resulted in $97 \%$ removal of $\mathrm{Zn}$ (II) contaminating ions and reached a maximum adsorption capacity of $27.5 \mathrm{mg} \mathrm{Zn}$ per gram of bio-adsorbent. The adsorption processes were found to follow a pseudo-second order model. The error function sum of square error indicated the Freundlich isotherm (non-linear regression) as best fit model. The obtained results are particularly interesting for material selection in wastewater treatment technologies based on contaminant adsorption.

Keywords: fruit peels; heavy metal removal; wastewater treatment; adsorption; kinetics

\section{Introduction}

Water contamination is one of the most important and high priority research topics around the world, as the availability of clean water is not only essential for life but it is also of paramount importance for social and economic development [1]. Unfortunately, as agricultural, industrial, and urban activities flourish, the pollution level in the environment and particularly in water bodies also increases [2,3]. Organic matter, nutrients, fertilizers, pesticides, dyes, pharmaceuticals, personal care products, oils, and heavy metals can be counted among the commonly found contaminants [4]. Furthermore, these organic and inorganic pollutions directly affect human health and aquatic ecosystems [5].

Particularly, contamination of water by heavy metals is worrisome because of their persistence and the possibilities of bioaccumulation and biomagnification [6,7]. These 
non-degradable and potentially toxic contaminants include arsenic, chromium, lead, cadmium, mercury, copper, and zinc, among others [8,9]. Their presence in water bodies is associated with natural and anthropogenic sources such as atmospheric precipitation, geological weathering, coal combustion, electroplating, leather tanning, and mining industry discharges [10]. The potential ecological impact of heavy metals and their effect on human health demand the development of effective treatment methods to remove them from water and wastewaters.

Zinc is one of the essential elements for life when it acts as a micronutrient. Nevertheless, in larger quantities, it is considered a toxic metal, and it was classified as such by the US Environmental Protection Agency [11]. Zinc can be used in several applications including protective layers for aluminum, in the galvanized steel industries, in the production of alloys, ceramics, rubbers, batteries, cosmetics and paints [12,13]. Due to vast industrial use, $\mathrm{Zn}$ (II) ion residues in wastewaters have been found to reach concentrations up to $54 \mathrm{mg} \cdot \mathrm{L}^{-1}$ [10]. On the other hand, it has been defined that the concentration of $\mathrm{Zn}$ (II) ions in drinking water should be less than $5 \mathrm{mg} \cdot \mathrm{L}^{-1}$ due to problems associated with its organoleptic properties as color, taste and odor [11]. Zn(II) ion concentrations greater than $15 \mathrm{mg} \cdot \mathrm{L}^{-1}$ could cause health problems such as diarrhea, dehydration, abdominal pain, fever, nausea, damage to pancreas, anemia, and vomiting. Excessive exposure to, or intake of, zinc can deteriorate the liver [14]. Long-term exposure to high amounts of zinc can affect the brain, causing focal neuronal deficits and lethargy and can also increase the risk of prostate cancer [15]. Zn(II) is also related to Alzheimer's disease [16]. Finally, its presence in rivers could cause bioaccumulation in aquatic organisms, indirectly affecting humans [17].

There are different methods to remove heavy metals from industrial wastewaters, including chemical precipitation, electrocoagulation, reverse osmosis, ion exchange, among others [18-21]. Nevertheless, most of them show disadvantages due to the technological requirements for installation, operation and maintenance, generation of toxic byproducts and high cost compared with methods such as adsorption [8,22-24]. Adsorption can be considered a promising alternative thanks to its relative simplicity, low cost, and high efficiency [25].

Activated carbon is one of the most widely used adsorbents for removing heavy metals from water $[26,27]$. However, the relatively high cost of materials such as this one has triggered the development of a variety of novel bio-adsorbents [28,29]. Bacteria (Bacillus subtillis, Burkholderia cepacia), fungi (Rhizopus arrhizus, Hypholoma fasciculation), yeasts (Saccharomyces cerevisiae), and algae are some of the alternatives used to eliminate $\mathrm{Zn}(\mathrm{II})$ ions [30,31].

However, relatively recent studies have also explored the possibility of removing Zn(II) ions by using agro-industrial residues such as orange peels, rapeseed residues, banana peel, dead biomass (Variovax paradoxus and Arthrobacter viscousus), sugarcane bagasse, and lemon grass. These low-cost bio-adsorbents could reach $\mathrm{Zn}$ (II) ions removal efficiencies close to those of activated carbon (90\% and higher) [32-36], which demonstrates the high potential of using agro-industrial residues for treating heavy metal contaminated waters.

Agro-industrial residues such as fruit peels contain hemicellulose, lignin, lipids, proteins, simple sugars, water, and pectin in their structure $[37,38]$. These components are involved in bio-adsorption processes due to their high content of carboxyl and hydroxyl groups [39]. However, in the absence of a prior treatment, agro-industrial residues could generate problems related to chemical and biological oxygen demand, organic carbon and a low adsorption capacity [40-42]. Therefore, for wastewater treatment, it is necessary to modify the agro-industrial residues to remove the soluble organic compounds and increase the adsorption capacity [43]. This is particularly relevant when these materials are used in wastewater treatment technologies based on adsorption (e.g., bio-filtration) [44]. Moreover, the material used as bed support not only plays a fundamental role in the contaminant removal but has an impact on the treatment cost [45]. 
In this work, we study the use fruit peels to obtain novel bio-adsorbents based on agroindustrial wastes for $\mathrm{Zn}$ (II) ion contaminants from synthetic wastewaters. The adsorption performance was studied upon chemical modification with sodium hydroxide and calcium salt, as an approach to improve the adsorption capacity. The adsorption performance of the bio-adsorbents was analyzed also with the starting waste peels, namely obtained from banana, granadilla, and orange peels. The Zn(II) ion removal efficiencies, adsorption capacity and contact time were determined as a function of the concentration of the base and salt solutions used for treatment.

\section{Materials and Methods}

\subsection{Materials}

Peels of banana (Musa paradisiaca L.) (BP), granadilla (Passiflora ligularis) (GP), and orange (Citrus aurantium) $(\mathrm{OP})$ were used as raw materials for obtaining bio-adsorbents. They were collected from a local fruit market in Quito, Ecuador. Calcium acetate $\left(\mathrm{Ca}\left(\mathrm{CH}_{3} \mathrm{COO}\right)_{2}\right)$ and sodium hydroxide $(\mathrm{NaOH})$, as well as zinc chloride $\left(\mathrm{ZnCl}_{2}\right)$ and hydrochloric acid $(\mathrm{HCl})$, were used for the peel modification and formulation of synthetic water solutions, respectively. The chemicals were reagent grade (Merck, Burlington, MA, USA) and used as received.

\subsection{Bio-Adsorbent Preparation}

The fruit peel wastes were washed with water in order to clean the surface from impurities [46] and further cut into pieces $\left(2 \times 2 \mathrm{~cm}^{2}\right)$ and oven-dried at $60{ }^{\circ} \mathrm{C}$ for $24 \mathrm{~h}$. Next, the dry peel pieces were crushed in a knife-mill (Thomas Wiley, model 3379-K05, Thomas Scientific, Swedesboro, NJ, USA) and sieved to a particle size between 125 and $841 \mu \mathrm{m}$.

To obtain the bio-adsorbents, the natural dye was removed by dispersing $30 \mathrm{~g}$ of fruit peel particles in $600 \mathrm{~mL}$ of water for $1 \mathrm{~h}$. The peel particles were recovered from the supernatant by centrifugation at $1000 \mathrm{rpm}$ for $20 \mathrm{~min}$. This process was repeated until the supernatant got transparent. The peel particles were finally dried at $60^{\circ} \mathrm{C}$ for $24 \mathrm{~h}$. The bio-adsorbents prepared from banana, granadilla, and orange peels were named as BP, GP, and $\mathrm{OP}$, respectively.

Further, a chemical modification of the peel particles was performed by treating them successively with $\mathrm{NaOH}$ and $\mathrm{Ca}\left(\mathrm{CH}_{3} \mathrm{COO}\right)_{2}$ solutions of varying concentration each: 0.2 , 0.5 , and $0.8 \mathrm{M}$ [34]. To this end, $30 \mathrm{~g}$ of peel particles were first added to $500 \mathrm{~mL} \mathrm{NaOH}$ solution and stirred at $1000 \mathrm{rpm}$ for $2 \mathrm{~h}$. The peel particles were centrifuged and washed with water until supernatant reached $\mathrm{pH} 7$ and further dried at $45^{\circ} \mathrm{C}$ for $4 \mathrm{~h}$. Next, $20 \mathrm{~g}$ of $\mathrm{NaOH}$-treated fruit peel particles were added to $500 \mathrm{~mL} \mathrm{Ca}\left(\mathrm{CH}_{3} \mathrm{COO}\right)_{2}$ solution at $\mathrm{pH} 5$ for $24 \mathrm{~h}$. The $\mathrm{pH}$ of the mixtures was adjusted at $\mathrm{pH} 5 \pm 0.5$ using $\mathrm{NaOH}(1.0 \mathrm{~N})$ or $\mathrm{HCl}$ $(1.0 \mathrm{~N})$ solutions. The modified peel particles were centrifuged and rinsed to remove the excess of calcium. This process was carried out at room temperature and repeated three times. Finally, peel particles were dried at $60^{\circ} \mathrm{C}$ for $24 \mathrm{~h}[34,47]$. The modified banana, granadilla, and orange peel bio-adsorbents were named as $\mathrm{BP}_{\mathrm{x}}, \mathrm{GP}_{\mathrm{x}}$, and $\mathrm{OP}_{\mathrm{x}}$, respectively, where $\mathrm{x}$ is the concentration of the chemical solutions used for their modification, namely $0.2,0.5$, and $0.8 \mathrm{M}$.

\subsection{Characterization}

The moisture content of the BP, GP, and OP bio-adsorbents were determined according to ASTM D4442-16 (method A) and extractives, lignin, hemicellulose, and cellulose concentrations of dry samples were established through ASTM D1107-96 (2013) and ASTM D1106-13, respectively $[48,49]$. The thermal stability of the bio-adsorbents was evaluated by using thermogravimetry analysis (TGA) on a TGA Q500 (TA Instruments, New Castle, DE, USA) at a heating rate of $10{ }^{\circ} \mathrm{C} \mathrm{min}^{-1}$ in a temperature range from 20 to $1000{ }^{\circ} \mathrm{C}$ in static air atmosphere [50,51]. The main functional groups of the unmodified and modified bio-adsorbents before and after metal uptake were identified by using Fourier transform 
infrared spectroscopy (FT-IR) on a Spectrum 200 spectrometer (Perkin Elmer, Waltham, MA, USA) within the $4000-500 \mathrm{~cm}^{-1}$ range, and the morphology of the bio-adsorbents was studied using a PSEM eXpress scanning electron microscope (SEM) (ASPEX, Delmont, PA, USA) working at $20 \mathrm{kV}$ [50-52].

\subsection{Adsorption Experiments}

Batch bio-adsorption experiments were performed at room temperature to study the $\mathrm{Zn}$ (II) ion adsorption. Adsorption of $\mathrm{Zn}(\mathrm{II})$ ions was conducted using $1 \mathrm{~g}$ bio-adsorbent in $100 \mathrm{~mL}$ of $50 \mathrm{mg} \cdot \mathrm{L}^{-1} \mathrm{ZnCl}_{2}$ solution with magnetic stirring at $150 \mathrm{rpm}$ for $240 \mathrm{~min}$. The $\mathrm{pH}$ was measured using a $\mathrm{pH}$ meter (Mettler Toledo, FiveEas F20, Columbus, OH, USA) and it was adjusted to $5.0 \pm 0.5$ by adding either $0.1 \mathrm{~mol} \cdot \mathrm{L}^{-1} \mathrm{NaOH}$ or $0.1 \mathrm{~mol} \cdot \mathrm{L}^{-1} \mathrm{HCl}$ in all batch tests. After the adsorption, the suspension was filtered and the concentration $\mathrm{Zn}$ (II) ions in solution was determined by spectrophotometry analysis (HACH model DR 1900) (HACH, Loveland, CO, USA) using the Zincon method (Method 8009) [53,54]. All experiments were performed in triplicate.

Adsorption kinetics profiles were determined with a contact time from 0 to $4 \mathrm{~h}$ [34]. The removal data of $\mathrm{Zn}$ (II) ions using banana, granadilla, and orange peels chemically modified using $0.8 \mathrm{~mol} \cdot \mathrm{L}^{-1}$ solutions of $\mathrm{NaOH}$ and $\mathrm{Ca}\left(\mathrm{CH}_{3} \mathrm{COO}\right)_{2}$ were fitted by pseudofirst model and by a pseudo-second order model, given by Equations (1) and (2) [55,56]:

$$
\begin{gathered}
\log \left(\mathrm{q}_{\mathrm{e}}-\mathrm{q}_{\mathrm{t}}\right)=\log \left(\mathrm{q}_{\mathrm{e}}\right)-\frac{\mathrm{k}_{1}}{2.303} \mathrm{t} \\
\frac{\mathrm{t}}{\mathrm{q}_{\mathrm{t}}}=\frac{1}{\mathrm{k}_{2} \times \mathrm{q}_{\mathrm{e}}^{2}}+\frac{\mathrm{t}}{\mathrm{q}_{\mathrm{e}}},
\end{gathered}
$$

where $\mathrm{k}_{1}\left(\mathrm{~min}^{-1}\right)$ is the kinetics constant of pseudo-first order, $\mathrm{k}_{2}$ is the kinetics constant of pseudo-second order ( $\mathrm{g}$ bio-adsorbent $/ \mathrm{mg} \mathrm{Zn} / \mathrm{min}$ ); $\mathrm{q}_{\mathrm{e}}$ is the capacity of biosorption in equilibrium ( $\mathrm{mg} \mathrm{Zn} / \mathrm{g}$ bio-adsorbent) and $\mathrm{q}_{\mathrm{t}}$ is the biosorption capacity ( $\mathrm{mg} \mathrm{Zn} / \mathrm{g}$ bioadsorbent) at time $t(\mathrm{~min})$. The values of $\mathrm{k}_{2}$ and $\mathrm{q}_{\mathrm{e}}$ allow to determine the initial velocity of adsorption $\mathrm{h}$ ( $\mathrm{mg} \mathrm{Zn} / \mathrm{g}$ adsorbent/min), which is given by Equation (3):

$$
\mathrm{h}=\mathrm{k}_{2} \times \mathrm{q}_{\mathrm{e}^{\prime}}^{2}
$$

To obtain $k_{2}$ and $q_{e}, t / q_{t}$ were analyzed as a function of time $(t)$. Adsorption isotherms were obtained by adding $1 \mathrm{~g}$ of peel particles to $100 \mathrm{~mL}$ of $\mathrm{Zn}$ (II) solutions with concentrations between 25 and $350 \mathrm{mg} \cdot \mathrm{L}^{-1}$, at $\mathrm{pH} 5.0 \pm 0.5$, during the equilibrium time [50]. Further, the obtained data was fitted to isotherm models, namely Freundlich and Langmuir by using the linearized forms in Equations (4) and (5) [50,57] and the non-linear forms in Equations (6) and (7) [58]. The adsorption model with the best fit was indicated by the highest correlation coefficient.

$$
\begin{gathered}
\log \mathrm{q}_{\mathrm{e}}=\frac{1}{\mathrm{n}} \log \mathrm{C}_{\mathrm{e}}+\log \mathrm{K}_{\mathrm{F}} \\
\frac{\mathrm{C}_{\mathrm{e}}}{\mathrm{q}_{\mathrm{e}}}=\frac{1}{\left(\mathrm{q}_{\mathrm{m}} \times \mathrm{K}_{\mathrm{L}}\right)}+\frac{1}{\mathrm{q}_{\mathrm{m}}} \mathrm{C}_{\mathrm{e}} \\
\mathrm{q}_{\mathrm{e}}=\mathrm{K}_{\mathrm{F}} \mathrm{C}_{\mathrm{e}}^{1 / \mathrm{n}} \\
\mathrm{q}_{\mathrm{e}}=\frac{\mathrm{C}_{\mathrm{e}} \mathrm{q}_{\mathrm{m}} \mathrm{K}_{\mathrm{L}}}{1+\mathrm{K}_{\mathrm{L}} \mathrm{C}_{\mathrm{e}}}
\end{gathered}
$$

where $\mathrm{q}_{\mathrm{e}}$ is the amount of solute adsorbed at equilibrium per adsorbent unit weight $\left(\mathrm{mg} \cdot \mathrm{g}^{-1}\right), \mathrm{C}_{\mathrm{e}}$ represents the concentration of solute at equilibrium $\left(\mathrm{mg} \cdot \mathrm{L}^{-1}\right), \mathrm{K}_{\mathrm{F}}$ is the constant of the Freundlich equation related to adsorption capacity $\left(\mathrm{L}^{1 / \mathrm{n}} \cdot \mathrm{mg}^{1-1 / \mathrm{n}} \mathrm{g}^{-1}\right), n$ is the coefficient of the Freundlich equation related to heterogeneity, and $\mathrm{q}_{\mathrm{m}}$ represents the maximum monolayer capacity $\left(\mathrm{mg} \cdot \mathrm{g}^{-1}\right)$ while $\mathrm{K}_{\mathrm{L}}$ is the empirical constant of the Langmuir 
equation $\left(\mathrm{L} \cdot \mathrm{mg}^{-1}\right)$. The separation factor or equilibrium parameter $\left(\mathrm{R}_{\mathrm{L}}\right)$ is a dimensionless constant and a fundamental characteristic of the Langmuir isotherm. This constant is defined according to Equation (8) [59], where $\mathrm{K}_{\mathrm{L}}$ is the Langmuir constant $\left(\mathrm{L} \cdot \mathrm{mg}^{-1}\right)$ and is associated with the adsorption energy, and $C_{o}$ is the initial concentration $\left(\mathrm{mg} \mathrm{Zn} \mathrm{L}^{-1}\right) . R_{\mathrm{L}}$ is indicative of the isotherm shape and the nature of the adsorption, that is, when $R_{L}=0$, the adsorption is reversible, when $0<\mathrm{R}_{\mathrm{L}}<1$, then the adsorption is favored, if $\mathrm{R}_{\mathrm{L}}=1$ the adsorption is linear and when $\mathrm{R}_{\mathrm{L}}>1$, the adsorption is not favored [59]:

$$
\mathrm{R}_{\mathrm{L}}=\frac{1}{\left(1+\mathrm{K}_{\mathrm{L}} \times \mathrm{C}_{\mathrm{o}}\right)}
$$

The data were fit to these kinetic and isotherm models because they are the classic models and have shown to adjust well to the equilibrium models $\left(R^{2} \approx 1\right)$, described by bio-adsorbents residues in the removal of several contaminants [60]. The data of the linear isotherm models was calculated and compared to that computed (Microsoft Excel SOLVER software, version 2016, Quito, Ecuador) for non-linear isotherm models, taking into account the sum of squares error (SSE) as error function which is necessary for optimization of the fitting [58].

\section{Results and Discussion}

Compounds such as cellulose, hemicellulose, lignin, glucose, galactose, arabinose, rhamnose, and xylose are involved in bio-adsorption processes as they have carboxyl and hydroxyl functional groups $[27,28,31,35,39,61,62]$. Table 1 shows moisture content and extractives, as well as lignin, hemicellulose, and cellulose content of unmodified banana, granadilla, and orange peels. These values are expressed as a percentage of the initial dry weight of materials [63]. As it can be observed in Table 1, the moisture contents for banana, granadilla, and orange peels are similar to those reported elsewhere $[31,35,61,64]$. The banana peels exhibit the highest moisture content $(89.1 \%)$ which could be due to some factors such as structural differences, genetic varieties, agronomic, and climatic conditions during growth $[64,65]$.

Table 1. Physical and chemical characteristics of banana, orange, and granadilla peels.

\begin{tabular}{cccc}
\hline Parameter (\%) & Banana Peels & Orange Peels & Granadilla Peels \\
\hline Lignin * & $16.6 \pm 1.1$ & $7.9 \pm 0.2$ & $16.9 \pm 0.6$ \\
Hemicellulose * & $15.9 \pm 0.1$ & $15.4 \pm 0.3$ & $10.1 \pm 0.7$ \\
Cellulose * & $62.5 \pm 1.0$ & $55.7 \pm 0.9$ & $24.6 \pm 1.3$ \\
Ethanol-toluene extractives * & $4.7 \pm 0.6$ & $21.1 \pm 1.2$ & $48.5 \pm 0.7$ \\
Moisture & $89.1 \pm 0.3$ & $68.7 \pm 0.4$ & $68.8 \pm 0.5$ \\
\hline
\end{tabular}

* Dry basis.

Lignin, hemicellulose, and cellulose are known to exhibit great sorption capacity of some pollutants [66]. Lignin is an organic polymer with polar functional groups that could bond chemically and interact with pollutant cations [66]. As can be observed in Table 1, banana and granadilla bio-adsorbents show similar lignin contents, while orange peels show the lowest value, in agreement with other studies on banana peels $[67,68]$ and orange peels $[39,69]$. On the other hand, granadilla peels are compared with passion fruit peels since these fruits belong to the same family [70] and showed lower lignin percentages than the values previously reported for yellow passion fruit peels [71]. Among other factors, this difference can be attributed to the stage of ripeness of the studied fruits [38].

Cellulose is a polymer with a large quantity of hydroxyl groups, bonded to hemicellulose by hydrogen bonds. This structure shows a highly reactive surface area which can adsorb cations. Therefore, adsorption capacity is increased when cellulose content is higher [72]. Banana dry peels show the highest cellulose percentage (62.5\%), compared to other values reported $[46,67,68,73]$. This is also the case for orange dry peels $(55.7 \%)$ [39], while granadilla dry peels exhibit the lowest $(24.6 \%)$. 
On the other hand, hemicellulose percentages of banana and orange peels are similar as reported elsewhere $[39,46,67,68,73]$. For yellow passion fruit peels, the hemicellulose and cellulose contents are of 39 and $26 \%$, respectively [74]. Factors such as the conditions in which the fruit was collected, type of species, state of ripeness of the fruit, conditions of cultivation, and the methods used in the peels characterization could explain this difference [75].

Extractives can be considered as phenolic substances which can interact with the contaminants [69]. The presence of extractives reduces the adsorption capacity of materials since these substances could fill the pores of the absorbent, preventing the adsorbate molecules from interacting with the active sites. Hence, a material with a high content of extractives shows a low adsorption capacity [76]. Granadilla peels exhibit the highest percentage of extractives, similar to that of yellow passion fruit peels [74]. On the other hand, banana peels showed the lowest value. Nevertheless, those results are quite different from those reported for banana and orange peels by previous authors $[68,69]$.

\subsection{Characterization of the Adsorbents}

Thermogravimetric analysis (TGA) was carried out on unmodified and modified bio-adsorbents which were previously dried. Figure 1 shows the decomposition according to the thermal profiles.

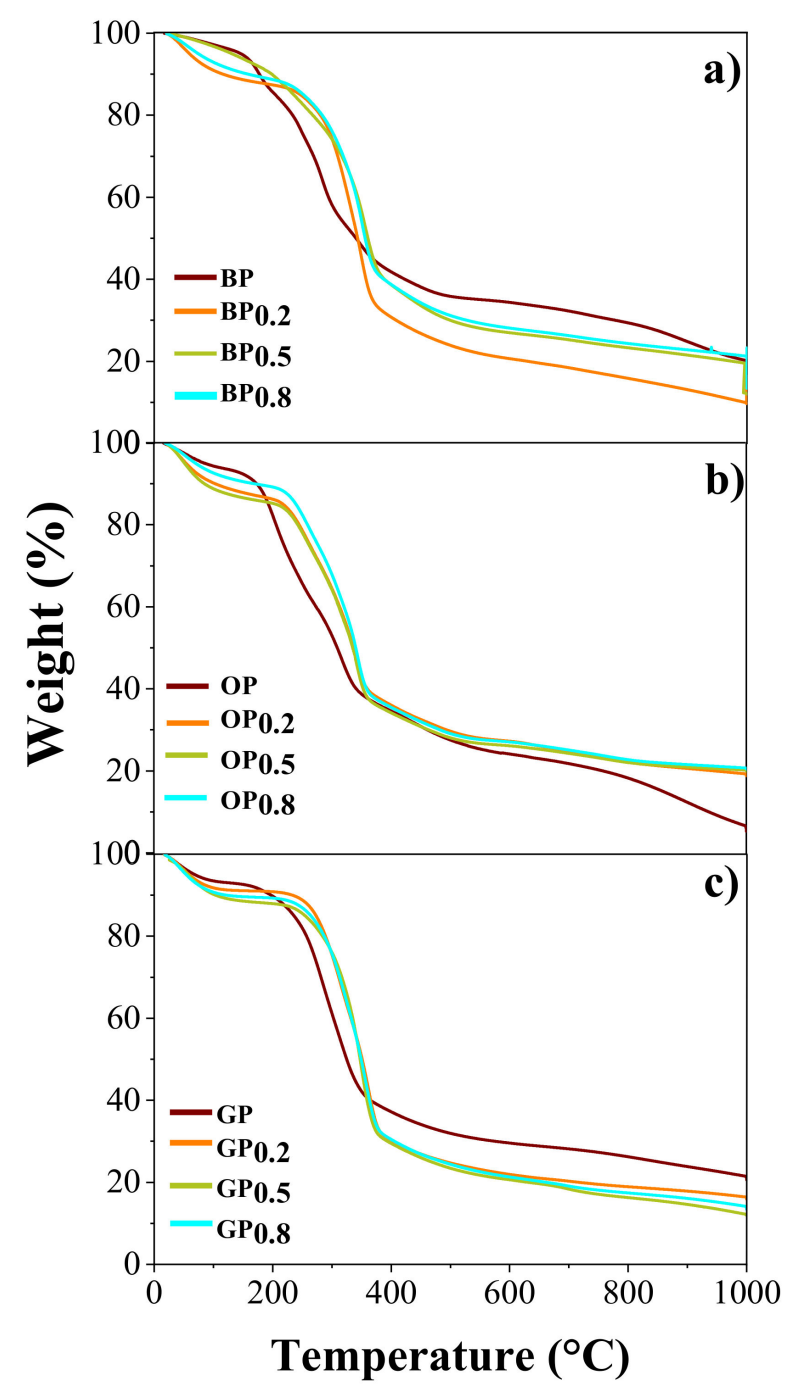

Figure 1. Thermogravimetric analysis profiles of (a) Banana (BP), (b) Orange (OP), and (c) Granadilla (GP) unmodified and chemically modified peels. 
As shown in Figure 1, unmodified bio-adsorbents show a first weight loss of about 2.5, 5.2 , and $8.2 \%$ for banana, granadilla, and orange peels, respectively, which was recorded at $70-100{ }^{\circ} \mathrm{C}$, and it is attributed to the evaporation of water [77]. Another clear weight loss was observed above $220-250{ }^{\circ} \mathrm{C}$, which corresponds to the degradation of hemicellulose and organic and/or aqueous extracts such as pectin, which represent the reduction of the volatile matter [77]. The next stage, between 390 and $400{ }^{\circ} \mathrm{C}$, represents the degradation of the cellulose found in each peel. The last stage corresponds to the degradation of lignin that occurs at temperatures above $400{ }^{\circ} \mathrm{C}$ [69].

The thermograms of the modified peels show a slight right shift in all the stages with respect to unmodified peels thermograms, which could be due to the presence of calcium in the peel structure because of the chemical treatment carried out [55]. Due to its resistance to temperature, calcium (melting temperature $842^{\circ} \mathrm{C}$ ) and its compounds act as thermal stabilizers of bio-adsorbents, this effect has also been observed when they are mixed with synthetic polymers [78].

Figure 2 shows FT-IR spectra obtained from the unmodified and the chemically modified bio-adsorbents, before and after the adsorption of $\mathrm{Zn}$ (II) ions. For exemplification, the spectra of adsorbents treated with $0.8 \mathrm{M}$ modifiers are presented.

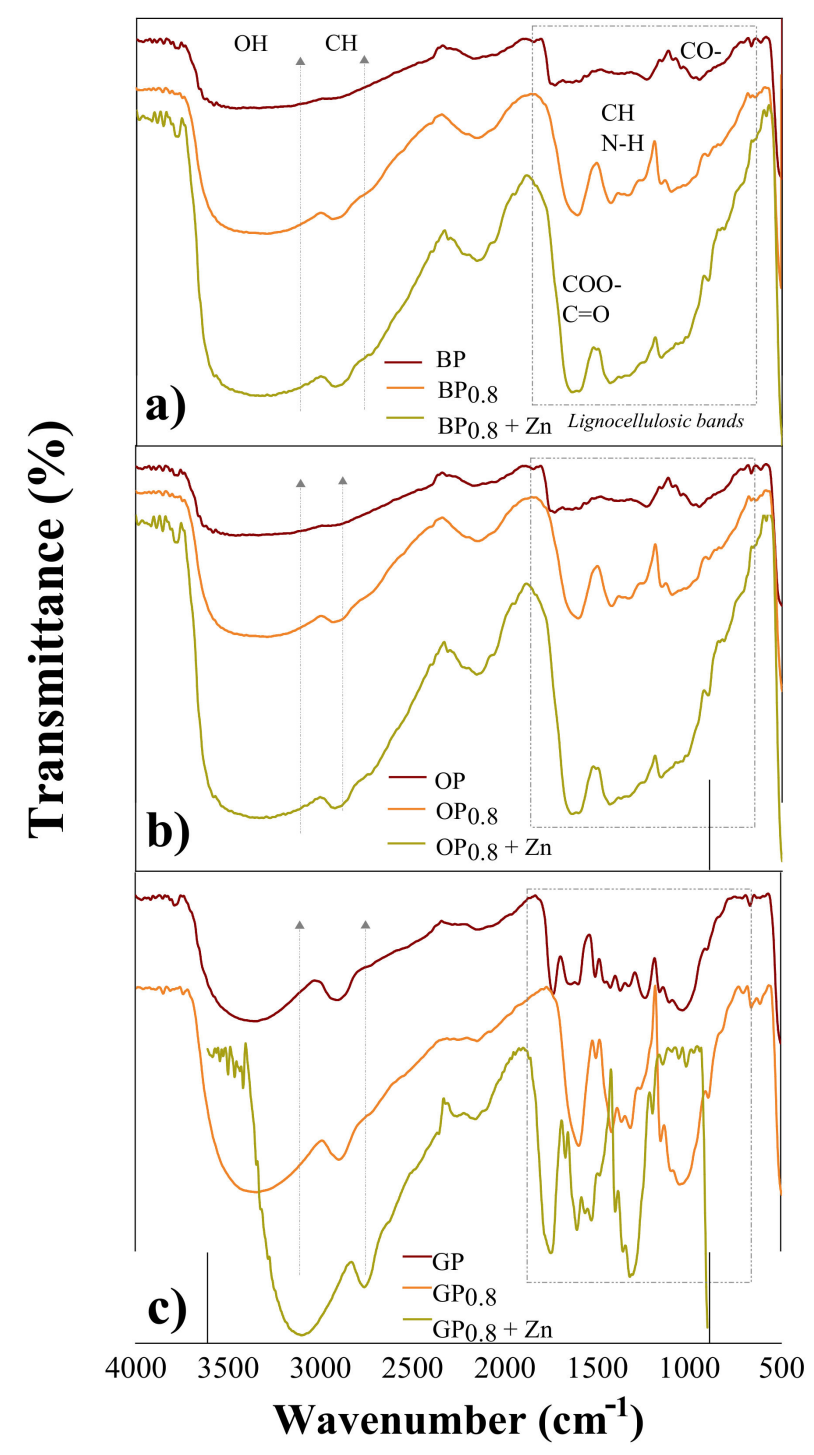

Figure 2. FT-IR spectra for (a) banana (BP), (b) orange (OP), and (c) granadilla (GP) bio-adsorbents before and after chemical treatment and the $\mathrm{Zn}(\mathrm{II})$ ion removal. 
As shown in Figure 2, banana, granadilla, and orange bio-adsorbent spectra show bands between $3600-3000 \mathrm{~cm}^{-1}$, which correspond to the hydroxyl group $\left(\mathrm{OH}^{-}\right)$. These bands are due to the stretching of the $\mathrm{OH}^{-}$bonds of cellulose, hemicellulose, lignin, citric acid, and water from the residual moisture of the peels [79]. The bands located between 3000 and $2800 \mathrm{~cm}^{-1}$ belong to the stretching of $\mathrm{C}-\mathrm{H}$ groups. The bands between 1744 and $1638 \mathrm{~cm}^{-1}$ correspond to the carboxylate ion $\left(\mathrm{COO}^{-}\right)$and the carbonyl ester group $(\mathrm{C}=\mathrm{O})$ stretching from aldehydes and ketones. The bands within the $1430-1455 \mathrm{~cm}^{-1}$ range indicate aliphatic and aromatic groups $(\mathrm{C}-\mathrm{H})$ associated to the in-plane vibrations from methyl, methylene, and methoxy groups. The bands around $1422-1420 \mathrm{~cm}^{-1}$ were assigned to N-H bending vibrations. The bands located withing $1300-1000 \mathrm{~cm}^{-1}$ range are assigned to the stretching vibration of carboxylic groups $(\mathrm{C}-\mathrm{O})$ from acids and alcohols. The identified groups are present in hemicellulose $\left(1246 \mathrm{~cm}^{-1}\right)$, lignin $\left(1518 \mathrm{~cm}^{-1}\right)$, lipids $\left(2927 \mathrm{~cm}^{-1}\right)$, and pectin $\left(1740 \mathrm{~cm}^{-1}\right)$, principal peel components [80,81]. The $\mathrm{O}-\mathrm{H}, \mathrm{N}-\mathrm{H}$, $\mathrm{C}-\mathrm{O}$, and $\mathrm{COO}^{-}$groups participate in sorption processes, being important sites for the pollutants location $[82,83]$.

Upon chemical modification with $0.8 \mathrm{M}$ modifiers, the bio-adsorbents spectra show changes in the bands located between 1700 and $1000 \mathrm{~cm}^{-1}$, which can be explained by the pre-treatment with $\mathrm{NaOH}$, which caused the degradation of the organic compounds (hemicellulose, lignin, lipids, and pectin) and generated the methyl ester group hydrolysis and the ester groups transformation into carboxylate ions [55,82]. This treatment solubilizes some compounds that could interfere with the adsorption process, changes pore structure and increases the surface area of peels. Additionally, $\mathrm{OH}^{-}$functional groups are incorporated during the basic activation $[83,84]$. This is evidenced by the increase of the bands between 1000 and $1700 \mathrm{~cm}^{-1}$ in the three bio-adsorbents (orange lines, Figure 2), and this is due to the high affinity of calcium ions for the carboxyl and amino groups present in the lignocellulosic groups [85]. The spectra of the modified bio-adsorbents after $\mathrm{Zn}$ (II) ion removal process show carboxylic $(\mathrm{C}-\mathrm{O})$, carbonyl ester $(\mathrm{C}=\mathrm{O})$, and hydroxyl $\left(\mathrm{OH}^{-}\right)$ groups located at a shorter wavelength than before the removal process. The displacement associated to these groups is related to their participation in the adsorption of $\mathrm{Zn}$ (II) ions, specifically for $\mathrm{OH}^{-}$groups. This indicates that the adsorption of the metal occurs on the bio-adsorbent surface $[55,86]$.

Figure 3 shows the peel adsorbents before and after chemical treatment (BP, OP, GP, and $\mathrm{BP}_{0.8}, \mathrm{OP}_{0.8}, \mathrm{GP}_{0.8}$, respectively). The micrographs of non-treated bio-adsorbents showed an irregular morphology. However, upon chemical treatment, the $\mathrm{BP}_{0.8}, \mathrm{OP}_{0.8}$, and $\mathrm{GP}_{0.8}$ peel particles showed a porous structure due to the removal of soluble substances in the basic media treatment. It can be clearly seen that the porosity is the best in case of $\mathrm{OP}_{0.8}$ bioadsorbent. This treatment would generate a greater specific surface area that could contribute to $\mathrm{Zn}$ adsorption [84,87]. These modified particles further showed a rougher and less porous surface upon the metal ions removal because the ions they have partially covered the pores of the peel structure $[84,88]$. 

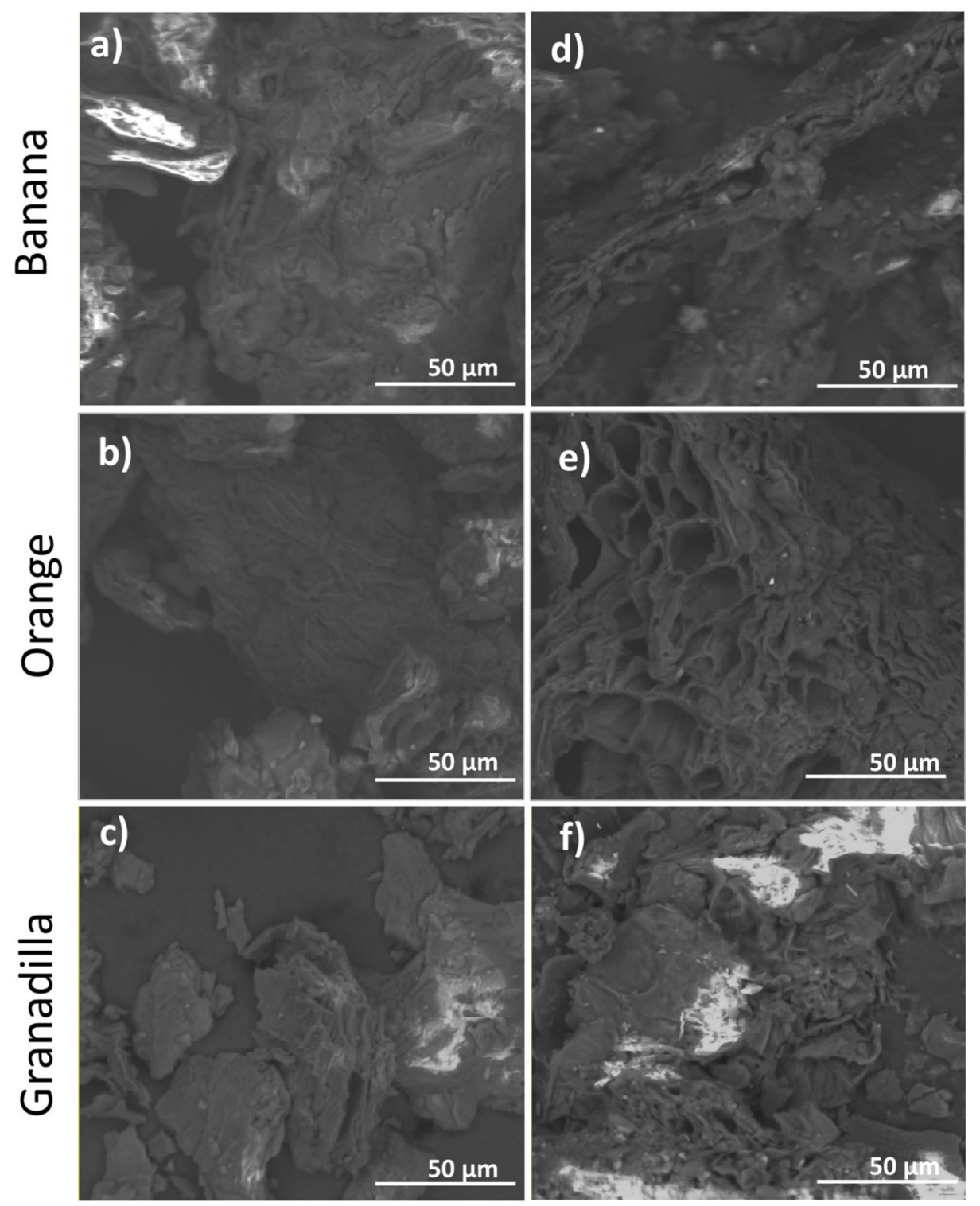

Figure 3. SEM micrographs of banana, orange, and granadilla peel adsorbents before (a, b and $\mathbf{c}$, respectively) and after the chemical treatment with $0.8 \mathrm{M}$ modifiers (d, e, and $\mathbf{f}$, respectively).

\subsection{Influence of Chemical Treatment on Zinc Adsorption}

The biosorption mechanisms depend on the metal or compound to be removed (adsorbate) and the organic material used as adsorbent (bio-adsorbent). These mechanisms include: (i) physical adsorption, where metal molecules are linked to the adsorbent surface due to electrostatic attraction forces, (ii) ion exchange (chemisorption), producing interchange between carboxyl, hydroxyl, amino, sulfonic groups and metal ions, and (iii) complexation, in which the union between the organic material and the metal is given by the formation of complexes on the material surface [17].

Table 2 shows the influence of the chemical treatments on the $\mathrm{Zn}(\mathrm{II})$ ion adsorption. As it can be observed, the adsorption efficiency of all fruit peel adsorbents increases upon chemical treatment. The best efficiency was recorded for the $0.8 \mathrm{M}$ concentration of the $\mathrm{NaOH}$ and $\mathrm{Ca}\left(\mathrm{CH}_{3} \mathrm{COO}\right)_{2}$ modifier solutions. The highest removal percentages were $92.57 \pm 0.24,97.13 \pm 0.21$, and $88.21 \pm 0.34 \%$ for the banana, orange, and granadilla peel particles modified using $0.8 \mathrm{~mol} \cdot \mathrm{L}^{-1}$ solutions. The adsorption increase could be attributed to the combined changes introduced by the chemical treatment, in agreement with Feng and Guo [34], considering factors such as: the modification of the peel surface in such a way 
so as to favor the physical adsorption. Thus, in agreement with SEM images, the adsorbent with best porosity (orange) exhibited the best performance. Furthermore, in agreement with FT-IR spectra, the carboxylate groups obtained by transformation of methyl ester groups are known to have a greater capacity for binding with metal ions which favors ion exchange during the adsorption process, so the calcium ions attached to the pectin chains are exchanged with the metal ions. The ion exchange could cause the increase of the bands between 1000 and 1700 and around $3000 \mathrm{~cm}^{-1}$, this is probably because zinc is heavier than calcium. Similar behavior was observed in a research in which pectinate gels were modified with calcium and zinc ions $[85,89,90]$. On the other hand, the higher content of cellulose in the banana and orange bio-adsorbents (see Table 1) could be accounted for their better removal performance with respect to granadilla adsorbent [34].

Table 2. Zn removal percentage achieved with bio-adsorbents.

\begin{tabular}{cccccc}
\hline Adsorbent & Zn Removal (\%) & Adsorbent & Zn Removal (\%) & Adsorbent & Zn Removal (\%) \\
\hline $\mathrm{BP}$ & $85.5 \pm 0.5$ & $\mathrm{OP}$ & $91.9 \pm 0.1$ & $\mathrm{GP}$ & $74.5 \pm 1.1$ \\
$\mathrm{BP}_{0.2}$ & $87.4 \pm 0.2$ & $\mathrm{OP}_{0.2}$ & $93.4 \pm 0.1$ & $\mathrm{GP}_{0.2}$ & $83.1 \pm 0.8$ \\
$\mathrm{BP}_{0.5}$ & $90.2 \pm 0.3$ & $\mathrm{OP}_{0.5}$ & $96.2 \pm 0.3$ & $\mathrm{GP}_{0.5}$ & $85.6 \pm 0.2$ \\
$\mathrm{BP}_{0.8}$ & $92.6 \pm 0.2$ & $\mathrm{OP}_{0.8}$ & $97.1 \pm 0.2$ & $\mathrm{GP}_{0.8}$ & $88.2 \pm 0.4$ \\
\hline
\end{tabular}

\subsection{Adsorption Kinetics}

Figure 4 shows the adsorption kinetic profiles for the removal of $\mathrm{Zn}(\mathrm{II})$ ions using the modified $\mathrm{BP}_{0.8}, \mathrm{GP}_{0.8}$, and $\mathrm{OP}_{0.8}$ peel adsorbents. These materials were chosen for the kinetics and isotherm studies because they are the ones that show the highest removal efficiencies. As can be observed, as the contact time increases, the $\mathrm{Zn}$ (II) ion removal also increases.

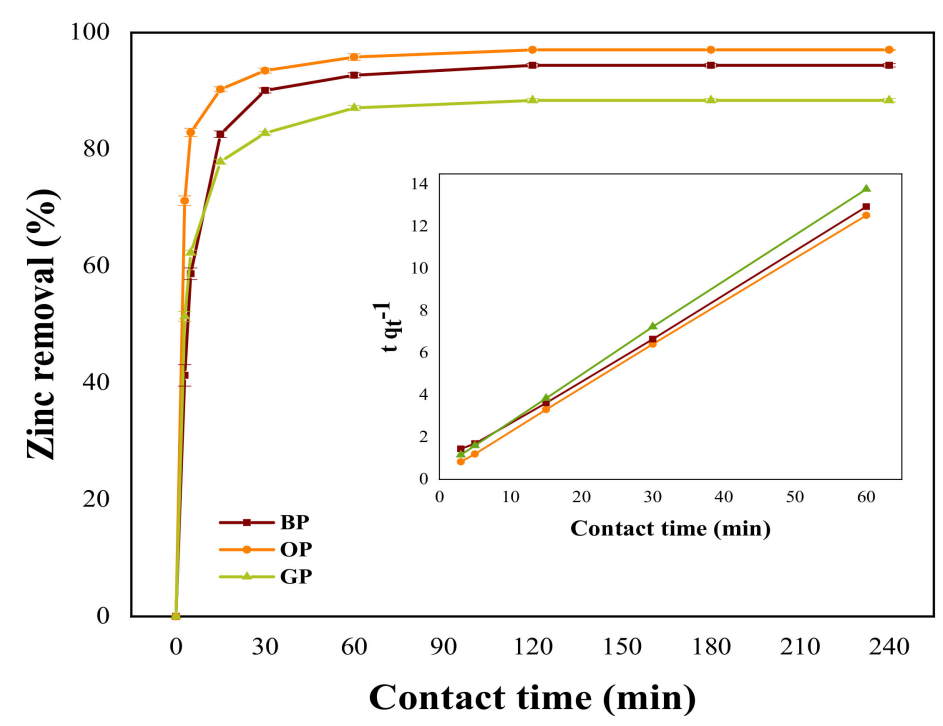

Figure 4. Kinetic profile of $\mathrm{Zn}(\mathrm{II})$ ion adsorption using the modified $\mathrm{BP}_{0.8}, \mathrm{OP}_{0.8}$, and $\mathrm{GP}_{0.8}$ peel bio-adsorbents. The inset shows the kinetics parameters.

The adsorption process can be divided in two zones: in the first zone (corresponding to the first $20 \mathrm{~min}$ ), the adsorption was very rapid as the bio-adsorbent surface was unsaturated and the active (or binding) sites are available. The binding sites are the places that receive the metal ions from the synthetic solution and where an ion exchange or a physical adsorption can occur [58,91]. In the second zone, the adsorption was slow due to the diffusion of $\mathrm{Zn}$ (II) ions to the internal part of the bio-adsorbent. At this stage, the equilibrium was reached for a contact time of $120 \mathrm{~min}$. The equilibrium time was used to obtain the adsorption isotherms. 
The kinetics of the removal of $\mathrm{Zn}(\mathrm{II})$ ions using banana, granadilla, and orange peels chemically modified using $0.8 \mathrm{~mol} \cdot \mathrm{L}^{-1}$ solutions of $\mathrm{NaOH}$ and $\mathrm{Ca}\left(\mathrm{CH}_{3} \mathrm{COO}\right)_{2}$ was fitted by both pseudo-first order model and a pseudo-second order model. The results of fitting are presented in Table 3. By comparing the correlation coefficients, it can be observed that those of pseudo-second order model fit better the processes with each adsorbent considered. This indicates that $\mathrm{Zn}$ biosorption velocity for each peel is controlled by chemical adsorption [55], which is also supported by the results of the adsorbent characterization (presence of active sites/functional groups).

Table 3. Kinetics parameters for $\mathrm{Zn}(\mathrm{II})$ ions removal using the chemically modified $\mathrm{BP}_{0.8}, \mathrm{GP}_{0.8}$, and $\mathrm{OP}_{0.8}$ bio-adsorbents.

\begin{tabular}{|c|c|c|c|c|c|c|c|c|c|c|c|}
\hline \multirow{2}{*}{$\begin{array}{c}\text { Peel } \\
\text { Adsorbents }\end{array}$} & \multicolumn{4}{|c|}{ Pseudo First Order } & \multicolumn{7}{|c|}{ Pseudo Second Order } \\
\hline & $\mathrm{q}_{\mathrm{e}}$ & {$\left[\frac{\mathrm{mg} \mathrm{Zn}}{\mathrm{g}}\right]$} & $\mathbf{k}_{1}\left[\min ^{-1}\right]$ & $\mathbf{R}^{2}$ & $\mathrm{q}_{\mathrm{e}}$ & {$\left[\frac{\mathrm{mg} \mathrm{Zn}}{\mathrm{g}}\right]$} & $\mathbf{k}_{2}$ & $\frac{\mathrm{g}}{\mathrm{mg} \mathrm{Zn} \times \min }$ & $\mathbf{h}$ & $\frac{\mathrm{mg} \mathrm{Zn}}{\mathrm{g} \times \min }$ & $\mathbf{R}^{2}$ \\
\hline $\mathrm{BP}_{0.8}$ & & 2.65 & 0.058 & 0.9145 & & 4.81 & & 0.09 & & 2.06 & 0.9997 \\
\hline $\mathrm{OP}_{0.8}$ & & 0.96 & 0.049 & 0.9303 & & 4.83 & & 0.27 & & 6.49 & 0.9999 \\
\hline $\mathrm{GP}_{0.8}$ & & 1.67 & 0.056 & 0.9720 & & 4.44 & & 0.14 & & 2.73 & 0.9998 \\
\hline
\end{tabular}

The values of qe show that the greater capacity of removal in equilibrium is achieved using the chemically modified $\mathrm{OP}_{0.8}$ peel bio-adsorbent, which is consistent with the results presented in the previous section. The values of initial velocity of adsorption (h) show that the $\mathrm{OP}_{0.8}$ bio-adsorbent has the highest initial velocity for the $\mathrm{Zn}(\mathrm{II})$ ion adsorption. According to Sirilamduan et al., a greater presence of binding sites on the peel surface would favor the first stage of adsorption [91]. The greatest presence of binding sites is the result of the composition and structure of the peels and the chemical treatment received.

\subsection{Adsorption Isotherms}

The obtained results were fitted to the linear forms of Langmuir and Freundlich models. Table 4 shows the parameters calculated for each bio-adsorbent. According to the correlation coefficients, the removal of $\mathrm{Zn}$ (II) ions using chemically modified bio-adsorbents fits the Langmuir model for all the bio-adsorbents, which is indicative of an adsorption process given by a monolayer adsorption on the peel surface. According to Dada et al., this is due to the presence of many binding sites with similar adsorption energies at the bio-adsorbent surface [92]. The adsorption isotherms (obtained by using the linear forms) for the removal of $\mathrm{Zn}(\mathrm{II})$ ions using the modified $\mathrm{BP}_{0.8}, \mathrm{GP}_{0.8}$ and $\mathrm{OP}_{0.8}$ bio-adsorbents were obtained, where the individual points of each isotherm represented the experimental data obtained from the equilibrium concentrations $\left(\mathrm{C}_{\mathrm{e}}\right)$, whereas the trend lines represented the isotherm obtained using the Langmuir constant $\left(\mathrm{K}_{\mathrm{L}}\right)$ and the maximum adsorption capacity $\left(\mathrm{q}_{\mathrm{m}}\right)$. It was observed that the biosorption capacity in equilibrium $\left(\mathrm{q}_{\mathrm{e}}\right)$ at low equilibrium concentrations ( $<75 \mathrm{mg} \mathrm{Zn} \mathrm{L}^{-1}$ ) increased, while at high equilibrium concentrations it tended to be constant [34]. The values of $C_{0}$ between 25 and $350 \mathrm{mg} \mathrm{Zn} \mathrm{L}{ }^{-1}$ resulted in separation factor $\mathrm{R}_{\mathrm{L}}$ values of $0.058-0.464,0.055-0.45$, and $0.028-0.286$ for banana, orange, and granadilla peel adsorbents, respectively. These results show that adsorption is favorable for each type of peel $\left(R_{L}<1\right)$ [93]. In addition, the values of $n$, coefficient of the Freundlich equation related to heterogeneity, can describe the condition of adsorption (good adsorption if $2<\mathrm{n}<10$, poor adsorption if $1<\mathrm{n}<2$, and difficult adsorption if $\mathrm{n}<1$ ). The results in the Table 4 show good adsorption of $\mathrm{Zn}(\mathrm{II})$ in the surface of $\mathrm{BP}_{0.8}$ and $\mathrm{OP}_{0.8}$ and poor adsorption in the surface of $\mathrm{GP}_{0.8}$. However, according to the correlation coefficients, the removal of $\mathrm{Zn}$ (II) ions using chemically modified bio-adsorbents fits the Langmuir model [21]. 
Table 4. Linear and non-linear adsorption isotherm parameters for the $\mathrm{Zn}(\mathrm{II})$ ions removal using the chemically modified $\mathrm{BP}_{0.8}, \mathrm{GP}_{0.8}$, and $\mathrm{OP}_{0.8}$ peel adsorbents.

\begin{tabular}{llll}
\hline Isotherm & $\mathbf{B P}_{\mathbf{0 . 8}}$ & $\mathbf{O P}_{\mathbf{0 . 8}}$ & $\mathbf{G P}_{\mathbf{0 . 8}}$ \\
\hline Linear Langmuir & & & \\
qm (mg/g) & 25.59 & 27.48 & 16.61 \\
$\mathrm{~K}_{\mathrm{L}}(\mathrm{L} / \mathrm{mg})$ & 0.046 & 0.099 & 0.049 \\
$\mathrm{R}^{2}$ & 0.9925 & 0.9945 & 0.9949 \\
\hline Linear Freundlich & & & \\
$\mathrm{KF}(\mathrm{mg} / \mathrm{g})$ (L/mg)1/n & 2.14 & 3.72 & 1.97 \\
$\mathrm{n}$ & 1.94 & 2.16 & 2.42 \\
$\mathrm{R}^{2}$ & 0.9738 & 0.9679 & 0.9763 \\
\hline Non-Linear Langmuir & & & \\
$\mathrm{qm}$ (mg/g) & 29.25 & 29.12 & 17.28 \\
$\mathrm{~K}_{\mathrm{L}}(\mathrm{L} / \mathrm{mg})$ & 0.024 & 0.055 & 0.034 \\
SSE & 12.47 & 19.11 & 9.42 \\
$\mathrm{R}^{2}$ & 0.9932 & 0.9950 & 0.9945 \\
\hline Non-Linear Freundlich & & & \\
KF (mg/g) (L/mg)1/n & 2.41 & 3.99 & 2.56 \\
$\mathrm{n}$ & 2.14 & 2.39 & 2.86 \\
SSE & 2.87 & 2.85 & 5.30 \\
$\mathrm{R}^{2}$ & 0.9925 & 0.9990 & 0.9940 \\
\hline
\end{tabular}

The adsorption of $\mathrm{Zn}(\mathrm{II})$ on the fruit peel bio-adsorbents was also analyzed with non-linear isotherm models as presented in Figure 5. The correlation coefficients are close to 0.9 , suggesting the acceptability of both linear and non-linear models. However, given that linear models might introduce errors during data transformation, one could consider the non-linear fitting as more appropriate. The error function SSE was employed for the best fit model and it varied considerably although the non-linear correlation coefficients were similar. Thus, lower SSE was obtained for Freundlich isotherms for all bio-adsorbents, which confirmed the fitness of the model.
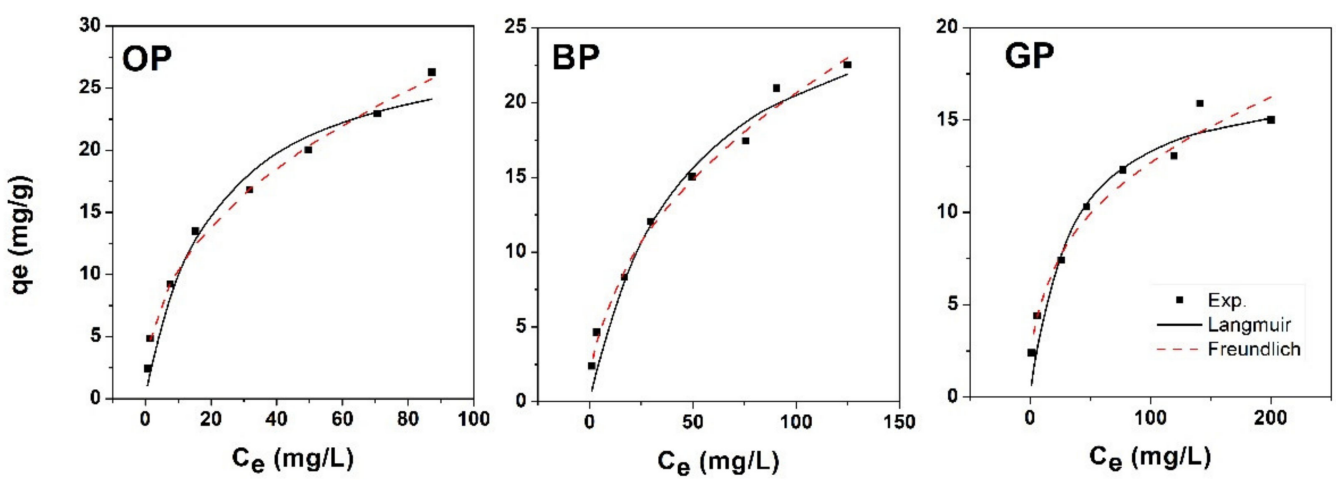

Figure 5. $\mathrm{Zn}(\mathrm{II})$ ion adsorption isotherms using chemically modified $\mathrm{BP}_{0.8}, \mathrm{GP}_{0.8}$, and $\mathrm{OP}_{0.8}$ peel adsorbents.

Table 5 compares the adsorption capacities, $\mathrm{q}_{\mathrm{m}}$, of the bio-adsorbents studied in this work and some bio-adsorbents previously studied in literature and obtained using different peels with and without treatment. As it can be observed, in several cases the adsorption capacities of $\mathrm{BP}_{0.8}$ and $\mathrm{OP}_{0.8}$ peel bio-adsorbents were higher than other reported bioadsorbents which is indicative of the significant potential the treatment with $\mathrm{NaOH}$ and $\mathrm{Ca}\left(\mathrm{CH}_{3} \mathrm{COO}\right)_{2}$ have on the bio-adsorbents efficiency a for removing $\mathrm{Zn}$ (II) ions from aqueous solutions. 
Table 5. Adsorption capacities of various bio-adsorbents.

\begin{tabular}{|c|c|c|c|c|c|c|}
\hline Adsorbent & Modification & $\begin{array}{c}\text { Adsorbent Dose } \\
\left(\mathrm{g} \mathrm{L}^{-1}\right)\end{array}$ & $\begin{array}{l}\text { Contact } \\
\text { Time (h) }\end{array}$ & $\mathrm{pH}$ & $\mathrm{q}_{\mathrm{m}}\left(\mathrm{mg} \mathrm{Zn} \mathrm{g}-{ }^{1}\right)$ & Ref. \\
\hline $\begin{array}{l}\text { Mimusops } \\
\text { Elengi }\end{array}$ & without & 1 & 1.5 & 5 & 16.39 & [94] \\
\hline Rapeseed waste & without & 1 & 24 & 5 & 13.86 & [32] \\
\hline Durian & $\begin{array}{l}\text { Acid-treated } \\
\mathrm{HCl}\end{array}$ & 5 & 4 & 8 & 36.75 & [58] \\
\hline $\mathrm{BP}_{0.8}$ & $\begin{array}{c}\mathrm{NaOH} \text { and } \\
\mathrm{Ca}\left(\mathrm{CH}_{3} \mathrm{COO}\right)_{2}\end{array}$ & 1 & 2 & 5 & 25.59 & This work \\
\hline Orange & without & 4 & 3 & 5 & 33.08 & [95] \\
\hline $\mathrm{OP}_{0.8}$ & $\begin{array}{c}\mathrm{NaOH} \text { and } \\
\mathrm{Ca}\left(\mathrm{CH}_{3} \mathrm{COO}\right)_{2}\end{array}$ & 1 & 2 & 5 & 27.48 & This work \\
\hline $\mathrm{GP}_{0.8}$ & $\begin{array}{c}\mathrm{NaOH} \text { and } \\
\mathrm{Ca}\left(\mathrm{CH}_{3} \mathrm{COO}\right)_{2}\end{array}$ & 1 & 2 & 5 & 16.61 & This work \\
\hline
\end{tabular}

\section{Conclusions}

Agro-industrial waste based bio-adsorbents were obtained from fruit peels to be investigated for $\mathrm{Zn}$ (II) ion removal from synthetic waters. The effect of the starting waste material was investigated, namely, the adsorbent was obtained from three types of fruit peels such as based on banana, orange, and granadilla peels. In order to improve the adsorption performance of the bio-adsorbents, a chemical treatment with $\mathrm{NaOH}$ and $\mathrm{Ca}\left(\mathrm{CH}_{3} \mathrm{OO}\right)_{2}$ was applied to remove them. The results indicate the efficiency of the obtained bio-adsorbents increases as the concentration of $\mathrm{NaOH}$ and $\mathrm{Ca}\left(\mathrm{CH}_{3} \mathrm{OO}\right)_{2}$ employed for chemical modification also increases. The highest $\mathrm{Zn}$ (II) ion removal efficiencies achieved using $\mathrm{BP}_{0.8}, \mathrm{OP}_{0.8}$, $\mathrm{GP}_{0.8}$ peels were $92.57,97.13$, and $88.21 \%$, respectively. The adsorption kinetics follow a model of pseudo-second order with equilibrium biosorption capacities for each peel of 4.79, 4.88 , and $4.46 \mathrm{mg} \mathrm{Zn/g}$ bio-adsorbent and an equilibrium time of $2 \mathrm{~h}$, while the Langmuir model is the one that best fits the behavior of the peels, with the maximum adsorption capacities being $25.59,27.48$, and $16.61 \mathrm{mg} \mathrm{Zn} \mathrm{g}^{-1}$ bio-adsorbent for banana, orange, and granadilla peels, respectively. Although the adsorption mechanism with such sorbents is a complex matter, the improved removal performance could be attributed to the greater presence of binding sites as a result of the composition and structure of the peels and the chemical treatment received. In the case of banana and orange-based bio-adsorbents, their higher content of cellulose with respect to granadilla one could be taken into account. The bio-adsorbents obtained from modified banana, granadilla, and orange peels represent inexpensive materials that could be used in the removal of heavy metal from contaminated effluents and constitutes a new green technology that takes advantage of agro-industrial residues. This work indicates chemically modified agro-industrial residues could also be used in treatment technologies, in which adsorption is one of the main mechanisms for pollutant removal.

Author Contributions: Conceptualization, D.C. and N.M.R.-L.; methodology, D.C.; N.M.R.-L. and C.E.A.-N.; investigation, D.C., N.M.R.-L., M.B.A. and V.H.G.; writing-original draft preparation, D.C., N.M.R.-L., C.E.A.-N.; M.B.A.; V.H.G. and A.I.P.; writing-review and editing, A.I.P., N.M.R.-L. and V.H.G. All authors have read and agreed to the published version of the manuscript.

Funding: This research was funded by Escuela Politécnica Nacional (project number PIMI-14-18).

Institutional Review Board Statement: Not applicable.

Informed Consent Statement: Not applicable.

Data Availability Statement: The data presented in this study are available on request from the corresponding author.

Conflicts of Interest: The authors declare no conflict of interest. The funders had no role in the design of the study; in the collection, analyses, or interpretation of data; in the writing of the manuscript, or in the decision to publish the results. 


\section{References}

1. Klara, P.; de la Rosa, F.M.; Kovačić, M.; Kušić, H.; Štangar, U.L.; Fresno, F.; Dionysiou, D.D.; Bozic, A.L. Recent achievements in development of $\mathrm{TiO} 2$-based composite photocatalytic materials for solar driven water purification and water splitting. Materials 2020, 13, 1338 .

2. Hoang, H.G.; Lin, C.; Tran, H.T.; Chiang, C.F.; Bui, X.T.; Cheruiyot, N.K.; Shern, C.C.; Lee, C.W. Heavy metal contamination trends in surface water and sediments of a river in a highly-industrialized region. Environ. Technol. Innov. 2020, 20, 101043. [CrossRef]

3. Li, Y.; Zhou, Q.; Ren, B.; Luo, J.; Yuan, J.; Ding, X.; Bian, H.; Yao, X. Trends and Health Risks of Dissolved Heavy Metal Pollution in Global River and Lake Water from 1970 to 2017. Rev. Environ. Contam. Toxicol. 2019, 238, 1-24.

4. Häder, D.P.; Banaszak, A.T.; Villafañe, V.E.; Narvarte, M.A.; González, R.A.; Helbling, E.W. Anthropogenic pollution of aquatic ecosystems: Emerging problems with global implications. Sci. Total Environ. 2020, 713, 136586. [CrossRef]

5. Basu, S.; Chanda, A.; Gogoi, P.; Bhattacharyya, S. Organochlorine pesticides and heavy metals in the zooplankton, fishes, and shrimps of tropical shallow tidal creeks and the associated human health risk. Mar. Pollut. Bull. 2021, 165, 112170. [CrossRef]

6. Turan, F.; Eken, M.; Ozyilmaz, G.; Karan, S.; Uluca, H. Heavy metal bioaccumulation, oxidative stress and genotoxicity in African catfish Clarias gariepinus from Orontes river. Ecotoxicology 2020, 29, 1522-1537. [CrossRef] [PubMed]

7. Pujari, M.; Kapoor, D. Heavy metals in the ecosystem: Sources and their effects. In Heavy Metals in the Environment; Elsevier: Amsterdam, The Netherlands, 2021; pp. 1-7.

8. Zamora-Ledezma, C.; Negrete-Bolagay, D.; Figueroa, F.; Zamora-Ledezma, E.; Ni, M.; Alexis, F.; Guerrero, V.H. Heavy metal water pollution: A fresh look about hazards, novel and conventional remediation methods. Press 2021, 22. [CrossRef]

9. Briffa, J.; Sinagra, E.; Blundell, R. Heavy metal pollution in the environment and their toxicological effects on humans. Heliyon 2020, 6, e04691. [CrossRef]

10. Kumar, V.; Parihar, R.D.; Sharma, A.; Bakshi, P.; Singh Sidhu, G.P.; Bali, A.S.; Karaouzas, I.; Bhardwaj, R.; Thukral, A.K.; Gyasi-Agyei, Y.; et al. Global evaluation of heavy metal content in surface water bodies: A meta-analysis using heavy metal pollution indices and multivariate statistical analyses. Chemosphere 2019, 236, 124364. [CrossRef]

11. EPA. Ambient Water Quality Criteria for Zinc; United States Environmental Protection Agency: Washington, DC, USA, 1980.

12. Borchers, N.; Clark, S.; Horstmann, B.; Jayasayee, K.; Juel, M.; Stevens, P. Innovative zinc-based batteries. J. Power Sources 2021, 484, 229309. [CrossRef]

13. Hussain, A.K.; Seetharamaiah, N.; Pichumani, M.; Chakra, C.S. Research progress in organic zinc rich primer coatings for cathodic protection of metals-A comprehensive review. Prog. Org. Coatings 2021, 153, 106040. [CrossRef]

14. Okereafor, U.; Makhatha, M.; Mekuto, L.; Uche-Okereafor, N.; Sebola, T.; Mavumengwana, V. Toxic metal implications on agricultural soils, plants, animals, aquatic life and human health. Int. J. Environ. Res. Public Health 2020, 17, 2204. [CrossRef]

15. Plum, L.M.; Rink, L.; Hajo, H. The essential toxin: Impact of zinc on human health. Int. J. Environ. Res. Public Health 2010, 7, 1342-1365. [CrossRef] [PubMed]

16. Xie, Z.; Wu, H.; Zhao, J. Multifunctional roles of zinc in Alzheimer's disease. Neurotoxicology 2020, 80, 112-123. [CrossRef] [PubMed]

17. Senthil Murugan, S.; Karuppasamy, R.; Poongodi, K.; Puvaneswari, S. Bioaccumulation pattern of zinc in freshwater fish Channa punctatus (Bloch.) after chronic exposure. Turkish J. Fish. Aquat. Sci. 2008, 59, 55-59.

18. Al-Shannag, M.; Al-Qodah, Z.; Bani-Melhem, K.; Qtaishat, M.R.; Alkasrawi, M. Heavy metal ions removal from metal plating wastewater using electrocoagulation: Kinetic study and process performance. Chem. Eng. J. 2015, 260, 749-756. [CrossRef]

19. Dominighini, C.; Muscia, L.; Cataldi, Z.; Scurati, C.; Olivero, M.; Gottardo, M. Analysis of reverse osmosis membranes in the treatment of water for human consumption. Health Environ. World Congr. 2016, 1, 123-129.

20. Ghosh, P.; Samanta, A.N.; Ray, S. Reduction of COD and removal of $\mathrm{Zn}^{2+}$ from rayon industry wastewater by combined electro-Fenton treatment and chemical precipitation. Desalination 2011, 266, 213-217. [CrossRef]

21. Guo, S.; Jiao, P.; Dan, Z.; Duan, N.; Zhang, J.; Chen, G.; Gao, W. Synthesis of magnetic bioadsorbent for adsorption of Zn(II), $\mathrm{Cd}(\mathrm{II})$ and $\mathrm{Pb}$ (II) ions from aqueous solution. Chem. Eng. Res. Des. 2017, 126, 217-231. [CrossRef]

22. Vidu, R.; Matei, E.; Predescu, A.M.; Alhalaili, B.; Pantilimon, C.; Tarcea, C.; Predescu, C. Removal of Heavy Metals from Wastewaters: A Challenge from Current Treatment Methods to Nanotechnology Applications. Toxics 2020, 8, 101. [CrossRef]

23. Otunola, B.O.; Ololade, O.O. A review on the application of clay minerals as heavy metal adsorbents for remediation purposes. Environ. Technol. Innov. 2020, 18, 100692. [CrossRef]

24. Beni, A.A.; Esmaeili, A. Biosorption an Efficient method for Removing Heavy Metals from Industrial Effluents: A Review. Environ. Technol. Innov. 2020, 17, 100503. [CrossRef]

25. Chai, W.S.; Cheun, J.Y.; Kumar, P.S.; Mubashir, M.; Majeed, Z.; Banat, F.; Ho, S.-H.; Show, P.L. A review on conventional and novel materials towards heavy metal adsorption in wastewater treatment application. J. Clean. Prod. 2021, 296, 126589. [CrossRef]

26. Anoop Krishnan, K.; Sreejalekshmi, K.G.; Vimexen, V.; Dev, V.V. Evaluation of adsorption properties of sulphurised activated carbon for the effective and economically viable removal of $\mathrm{Zn}$ (II) from aqueous solutions. Ecotoxicol. Environ. Saf. 2016, 124, 418-425. [CrossRef]

27. Kołodyńska, D.; Krukowska, J.; Thomas, P. Comparison of sorption and desorption studies of heavy metal ions from biochar and commercial active carbon. Chem. Eng. J. 2017, 307, 353-363. [CrossRef]

28. Wang, J.; Chen, C. Biosorbents for heavy metals removal and their future. Biotechnol. Adv. 2009, 27, 195-226. [CrossRef] 
29. Boni, M.; Chiavola, A.; Marzeddu, S. Application of Biochar to the Remediation of Pb-Contaminated Solutions. Sustainability 2018, 10, 4440. [CrossRef]

30. Hafshejani, L.D.; Nasab, S.B.; Gholami, R.M.; Moradzadeh, M.; Izadpanah, Z.; Hafshejani, S.B.; Bhatnagar, A. Removal of zinc and lead from aqueous solution by nanostructured cedar leaf ash as biosorbent. J. Mol. Liq. 2015, 211, 448-456. [CrossRef]

31. Xu, M.; McKay, G. Removal of heavy metals, lead, cadmium, and zinc, using adsorption processes by cost-effective adsorbents. In Adsorption Processes for Water Treatment and Purification; Bonilla-Petriciolet, A., Mendoza-Castillo, D.I., Reynel-Ávila, H.E., Eds.; Springer International Publishing: Cham, Switzerland, 2017; pp. 109-138. ISBN 9783319581361.

32. Paduraru, C.; Tofan, L.; Teodosiu, C.; Bunia, I.; Tudorachi, N.; Toma, O. Biosorption of zinc(II) on rapeseed waste: Equilibrium studies and thermogravimetric investigations. Process Saf. Environ. Prot. 2015, 94, 18-28. [CrossRef]

33. Rajczykowski, K.; Sałasińska, O.; Loska, K. Zinc Removal from the Aqueous Solutions by the Chemically Modified Biosorbents. Water. Air. Soil Pollut. 2018, 229, 6. [CrossRef]

34. Feng, N.C.; Guo, X.Y. Characterization of adsorptive capacity and mechanisms on adsorption of copper, lead and zinc by modified orange peel. Trans. Nonferrous Met. Soc. China 2012, 22, 1224-1231. [CrossRef]

35. Malkoc, S.; Kaynak, E.; Guven, K. Biosorption of zinc (II) on dead and living biomass of Variovorax paradoxus and Arthrobacter viscosus. Desalin. Water Treat. 2016, 57, 15445-15454. [CrossRef]

36. Kumari, P. Application of Sugarcane Bagasse for the Removal of Chromium (Vi) and Zinc (Ii) From Aqueous Solution. Int. Res. J. Eng. Technol. 2017, 04, 1670-1673.

37. Ahmed, M.J.; Hameed, B.H.; Hummadi, E.H. Insight into the chemically modified crop straw adsorbents for the enhanced removal of water contaminants: A review. J. Mol. Liq. 2021, 330, 115616. [CrossRef]

38. Cholico-González, D.; Ortiz Lara, N.; Fernández Macedo, A.M.; Chavez Salas, J. Adsorption Behavior of Pb (II), Cd (II), and Zn(II) onto Agave Bagasse, Characterization, and Mechanism. ACS Omega 2020, 5, 3302-3314. [CrossRef]

39. Bhatnagar, A.; Sillanpää, M. Utilization of agro-industrial and municipal waste materials as potential adsorbents for water treatment-A review. Chem. Eng. J. 2010, 157, 277-296. [CrossRef]

40. Tran, H.N.; Nguyen, H.C.; Woo, S.H.; Nguyen, T.V.; Vigneswaran, S.; Hosseini-Bandegharaei, A.; Rinklebe, J.; Kumar Sarmah, A.; Ivanets, A.; Dotto, G.L.; et al. Removal of various contaminants from water by renewable lignocellulose-derived biosorbents: A comprehensive and critical review. Crit. Rev. Environ. Sci. Technol. 2019, 49, 2155-2219. [CrossRef]

41. Ighalo, J.O.; Adeniyi, A.G. A mini-review of the morphological properties of biosorbents derived from plant leaves. SN Appl. Sci. 2020, 2, 509. [CrossRef]

42. Yoo, C.G.; Meng, X.; Pu, Y.; Ragauskas, A.J. The critical role of lignin in lignocellulosic biomass conversion and recent pretreatment strategies: A comprehensive review. Bioresour. Technol. 2020, 301, 122784. [CrossRef]

43. Anastopoulos, I.; Pashalidis, I.; Orfanos, A.G.; Manariotis, I.D.; Tatarchuk, T.; Sellaoui, L.; Bonilla-Petriciolet, A.; Mittal, A.; Núñez-Delgado, A. Removal of caffeine, nicotine and amoxicillin from (waste)waters by various adsorbents. A review. J. Environ. Manag. 2020, 261, 110236. [CrossRef]

44. Dacewicz, E.; Chmielowski, K. The Importance of Media in Wastewater Treatment. InTech Open 2018. [CrossRef]

45. Tejedor, J.; Cóndor, V.; Almeida-Naranjo, C.E.; Guerrero, V.H.; Villamar, C.A. Performance of wood chips/peanut shells biofilters used to remove organic matter from domestic wastewater. Sci. Total Environ. 2020, 738. [CrossRef] [PubMed]

46. Pathak, P.D.; Mandavgane, S.A.; Kulkarni, B.D. Fruit peel waste: Characterization and its potential uses. Curr. Sci. 2017, 113, 444-454. [CrossRef]

47. Hossain, M.A. Removal of Copper from Water by Adsorption onto Banana Peel as Bioadsorbent. Int. J. Geomate 2012, 2, 227-234. [CrossRef]

48. Chen, Y.W.; Hasanulbasori, M.A.; Chiat, P.F.; Lee, H.V. Pyrus pyrifolia fruit peel as sustainable source for spherical and porous network based nanocellulose synthesis via one-pot hydrolysis system. Int. J. Biol. Macromol. 2019, 123, 1305-1319. [CrossRef]

49. Yeh, C.-H.; Yang, T.-C. Utilization of Waste Bamboo Fibers in Thermoplastic Composites: Influence of the Chemical Composition and Thermal Decomposition Behavior. Polymers 2020, 12, 636. [CrossRef] [PubMed]

50. Farinella, N.V.; Matos, G.D.; Lehmann, E.L.; Arruda, M.A.Z. Grape bagasse as an alternative natural adsorbent of cadmium and lead for effluent treatment. J. Hazard. Mater. 2008, 154, 1007-1012. [CrossRef] [PubMed]

51. Kamsonlian, S.; Suresh, S.; Majumder, C.B.; Chand, S. Characterization of Banana and Orange Peels: Biosorption Mechanism. Int. J. Sci. Technol. Manag. 2011, 2, 1-7.

52. Memon, J.R.; Memon, S.Q.; Bhanger, M.I.; Memon, G.Z.; El-Turki, A.; Allen, G.C. Characterization of banana peel by scanning electron microscopy and FT-IR spectroscopy and its use for cadmium removal. Colloids Surf. B Biointerfaces 2008, 66, 260-265. [CrossRef]

53. Annadurai, G.; Juang, R.S.; Lee, D.J. Adsorption of heavy metals from water using banana and orange peels. Water Sci. Technol. 2003, 47, 185-190. [CrossRef]

54. Cardona, A.F.; Cabañas, D.D.; Zepeda, A. Evaluación del poder biosorbente de cáscara de naranja para la eliminación de metales pesados, $\mathrm{Pb}$ (II) y $\mathrm{Zn}$ (II) Evaluation of the power of orange peel biosorbent for the removal of heavy metals, $\mathrm{Pb}$ (II) and $\mathrm{Zn}$ (II). Ingeniería 2013, 17, 1-9.

55. Feng, N.C.; GUO, X.Y.; Liang, S. Kinetic and thermodynamic studies on biosorption of Cu (II) by chemically modified orange peel. Trans. Nonferrous Met. Soc. China 2009, 19, 1365-1370. [CrossRef] 
56. Yaneva, Z.L.; Koumanova, B.K.; Allen, S.J. Applicability comparison of different kinetic/diffusion models for 4-nitrophenol sorption on Rhizopus oryzae dead biomass. Bulg. Chem. Commun. 2013, 45, 161-168.

57. Ho, Y.S. Selection of optimum sorption isotherm. Carbon N.Y. 2004, 42, 2115-2116. [CrossRef]

58. Ngabura, M.; Hussain, S.A.; Ghani, W.A.W.A.; Jami, M.S.; Tan, Y.P. Utilization of renewable durian peels for biosorption of zinc from wastewater. J. Environ. Chem. Eng. 2018, 6, 2528-2539. [CrossRef]

59. Weber, T.W.; Chakravorti, R.K. Pore and solid diffusion models for fixed-bed adsorbers. AIChE J. 1974, 20, 228-238. [CrossRef]

60. Anastopoulos, I.; Massas, I.; Ehaliotis, C. Use of residues and by-products of the olive-oil production chain for the removal of pollutants from environmental media: A review of batch biosorption approaches. J. Environ. Sci. Health Part A 2015, 50, 37-41. [CrossRef]

61. Ashraf, M.; Wajid, A.; Mahmood, K.; Maah, M.; Yusoff, I. Low cost biosorbent banana peel (Musa sapientum) for the removal of heavy metals. Sci. Res. 2011, 6, 4055-4064.

62. Babarinde, A.; Ogundipe, K.; Sangosanya, K.T.; Akintola, B.D.; Hassan, A.-O.E. Comparative study on the biosorption of Pb (II), Cd (II) and Zn (II) using Lemon grass (Cymbopogon citratus): Kinetics, isotherms and thermodynamics. Chem. Int. 2016, 2, 89-102.

63. Hung, K.-C.; Yeh, H.; Yang, T.-C.; Wu, T.-L.; Xu, J.-W.; Wu, J.-H. Characterization of Wood-Plastic Composites Made with Different Lignocellulosic Materials that Vary in Their Morphology, Chemical Composition and Thermal Stability. Polymers 2017,9 , 726. [CrossRef] [PubMed]

64. Carvajal de Pabon, L.; Turbay Ceballos, S.; Marelly Álvarez, L.; Rodríguez, A.; Álvarez, M.; Bonilla, K.; Restrepo Escobar, S.; Parra, M. Relación entre los usos populares de la granadilla (passiflora ligularis juss) y su composición fitoquímica. Biotecnol. Sect. Agropecu. Agroind. BSAA 2014, 12, 191-202.

65. Pyar, H.; Peh, K.K. Chemical Compositions of Banana Peels (Musa sapientum) Fruits cultivated in Malaysia using proximate analysis. Res. J. Chem. Environ. 2018, 22, 108.

66. De Gisi, S.; Lofrano, G.; Grassi, M.; Notarnicola, M. Characteristics and adsorption capacities of low-cost sorbents for wastewater treatment: A review. Sustain. Mater. Technol. 2016, 9, 10-40. [CrossRef]

67. Palacios, S.; Ruiz, H.A.; Ramos-Gonzalez, R.; Martínez, J.; Segura, E.; Aguilar, M.; Aguilera, A.; Michelena, G.; Aguilar, C.; Ilyina, A. Comparison of physicochemical pretreatments of banana peels for bioethanol production. Food Sci. Biotechnol. 2017, 26, 993-1001. [CrossRef] [PubMed]

68. Oliveira, T.Í.S.; Rosa, M.F.; Cavalcante, F.L.; Pereira, P.H.F.; Moates, G.K.; Wellner, N.; Mazzetto, S.E.; Waldron, K.W.; Azeredo, H.M.C. Optimization of pectin extraction from banana peels with citric acid by using response surface methodology. Food Chem. 2016, 198, 113-118. [CrossRef]

69. Boumediene, M.; Benaïssa, H.; George, B.; Molina, S.; Merlin, A. Characterization of two cellulosic waste materials (orange and almond peels) and their use for the removal of methylene blue from aqueous solutions. Maderas. Cienc. Tecnol. 2014, 17. [CrossRef]

70. Rodriguez-Amaya, D.B. Passion Fruits. In Encyclopedia of Food Sciences and Nutrition; Elsevier: Amsterdam, The Netherlands, 2003; pp. 4368-4373.

71. Khawas, P.; Deka, S.C. Comparative Nutritional, Functional, Morphological, and Diffractogram Study on Culinary Banana (Musa ABB) Peel at Various Stages of Development. Int. J. Food Prop. 2016, 19, 2832-2853. [CrossRef]

72. El-Sayed, A.A.; Salama, M.; El-Rafie, M.H.; Emam, H.E. Modified Rice Straw as a Template in Syntheses of $\mathrm{Nano}^{\mathrm{TiO}} 2 \mathrm{Loaded}$ on Wool Fibers for Wastewater Treatment. J. Nat. Fibers 2017, 14, 297-309. [CrossRef]

73. Pereira, M.A.F.; Monteiro, C.R.M.; Pereira, G.N.; Júnior, S.E.B.; Zanella, E.; Ávila, P.F.; Stambuk, B.U.; Goldbeck, R.; de Oliveira, D.; Poletto, P. Deconstruction of banana peel for carbohydrate fractionation. Bioprocess Biosyst. Eng. 2020, 1, 3. [CrossRef]

74. Jaramillo, P.M.D.; Andreaus, J.; Neto, G.P.D.S.; Castro, C.F.D.S.; Filho, E.X.F. The characterization of a pectin-degrading enzyme from Aspergillus oryzae grown on passion fruit peel as the carbon source and the evaluation of its potential for industrial applications. Biocatal. Biotransform. 2015, 33, 310-322. [CrossRef]

75. López, G.J.; Cuarán, C.J.; Arenas, G.L.; Flórez, P.L. Usos potenciales de la cáscara de banano: Elaboración de un bioplástico. Rev. Colomb. Investig. Agroind. 2014, 1, 7-21. [CrossRef]

76. Pholosi, A.; Ofomaja, A.E.; Naidoo, E.B. Effect of chemical extractants on the biosorptive properties of pine cone powder: Influence on lead(II) removal mechanism. J. Saudi Chem. Soc. 2013, 17, 77-86. [CrossRef]

77. Kabenge, I.; Omulo, G.; Banadda, N.; Seay, J.; Zziwa, A.; Kiggundu, N. Characterization of Banana Peels Wastes as Potential Slow Pyrolysis Feedstock. J. Sustain. Dev. 2018, 11, 14. [CrossRef]

78. Lu, Y.; Wang, B.; Xue, M.; Lu, Y. Kinetics of thermal oxidative degradation of poly (vinyl chloride) containing Ca and Sn at low temperature. Waste Manag. 2021, 121, 52-58. [CrossRef]

79. Fonseca, J.; Albis, A.; Montenegro, A.R. Evaluation of zinc adsorption using cassava peels (Manihot esculenta) modified with citric acid. Contemp. Eng. Sci. 2018, 11, 3575-3585. [CrossRef]

80. Feng, N.; Guo, X.; Liang, S. Adsorption study of copper (II) by chemically modified orange peel. J. Hazard. Mater. 2009, 164, 1286-1292. [CrossRef]

81. Lahlali, R.; Song, T.; Chu, M.; Yu, F.; Kumar, S.; Karunakaran, C.; Peng, G. Evaluating changes in cell-wall components associated with clubroot resistance using fourier transform infrared spectroscopy and RT-PCR. Int. J. Mol. Sci. 2017, 18, 2058. [CrossRef] [PubMed] 
82. Li, X.; Tang, Y.; Cao, X.; Lu, D.; Luo, F.; Shao, W. Preparation and evaluation of orange peel cellulose adsorbents for effective removal of cadmium, zinc, cobalt and nickel. Colloids Surf. Physicochem. Eng. Asp. 2008, 317, 512-521. [CrossRef]

83. Gupta, H.; Gogate, P.R. Intensified removal of copper from waste water using activated watermelon based biosorbent in the presence of ultrasound. Ultrason. Sonochem. 2016, 30, 113-122. [CrossRef]

84. Afroze, S.; Sen, T.K.; Ang, H.M. Adsorption removal of zinc (II) from aqueous phase by raw and base modified Eucalyptus sheathiana bark: Kinetics, mechanism and equilibrium study. Process Saf. Environ. Prot. 2016, 102, 336-352. [CrossRef]

85. Assifaoui, A.; Loupiac, C.; Chambin, O.; Cayot, P. Structure of calcium and zinc pectinate films investigated by FTIR spectroscopy. Carbohydr. Res. 2010, 345, 929-933. [CrossRef]

86. Sari, A.; Tuzen, M.; Uluözlü, O.D.; Soylak, M. Biosorption of Pb (II) and Ni (II) from aqueous solution by lichen (Cladonia furcata) biomass. Biochem. Eng. J. 2007, 37, 151-158. [CrossRef]

87. Negro, V.; Ruggeri, B.; Mancini, G.; Fino, D. Recovery of D-limonene through moderate temperature extraction and pyrolytic products from orange peels. J. Chem. Technol. Biotechnol. 2017, 92, 1186-1191. [CrossRef]

88. De Carvalho, H.P.; Huang, J.; Zhao, M.; Liu, G.; Dong, L.; Liu, X. Improvement of Methylene Blue removal by electrocoagulation/banana peel adsorption coupling in a batch system. Alex. Eng. J. 2015, 54, 777-786. [CrossRef]

89. Wurm, F.; Rietzler, B.; Pham, T.; Bechtold, T. Multivalent Ions as Reactive Crosslinkers for Biopolymers-A Review. Molecules 2020, 25, 1840. [CrossRef]

90. Gawkowska, D.; Cybulska, J.; Zdunek, A. Structure-Related Gelling of Pectins and Linking with Other Natural Compounds: A Review. Polymers 2018, 10, 762. [CrossRef]

91. Sirilamduan, C.; Umpuch, C.; Kaewsarn, P. Removal of copper from aqueous solutions by adsorption using modify Zalacca edulis peel modify. Songklanakarin J. Sci. Technol. 2011, 33, 725-732.

92. Dada, A.O.; Olalekan, A. Langmuir, Freundlich, Temkin and Dubinin-Radushkevich Isotherms Studies of Equilibrium Sorption of Zn 2+ Unto Phosphoric Acid Modified Rice Husk. IOSR J. Appl. Chem. 2012, 3, 38-45.

93. Tran, H.N.; You, S.; Hosseini-bandegharaei, A.; Chao, H. Mistakes and inconsistencies regarding adsorption of contaminants from aqueous solutions: A critical review. Water Res. 2017, 120, 88-116. [CrossRef]

94. Kalyani, G.; Kumar, P.; King, P. Use of novel biosorbent mimusops elengi for removing zinc ions from aqueous solutions-Process optimization using central composite design. Rasayan J. Chem. 2016, 9, 510-525.

95. Marín, A.B.P.; Aguilar, M.I.; Ortuño, J.F.; Meseguer, V.F.; Sáez, J.; Lloréns, M. Biosorption of Zn (II) by orange waste in batch and packed-bed systems. J. Chem. Technol. Biotechnol. 2010, 85, 1310-1318. [CrossRef] 